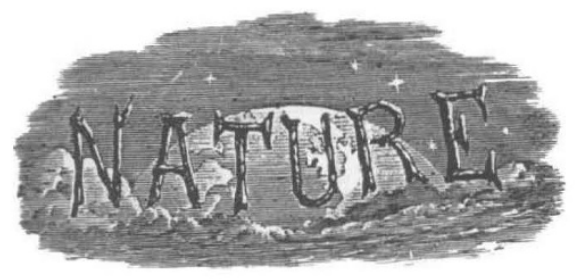

SATURDAY, FEBRUARY 8, I930.

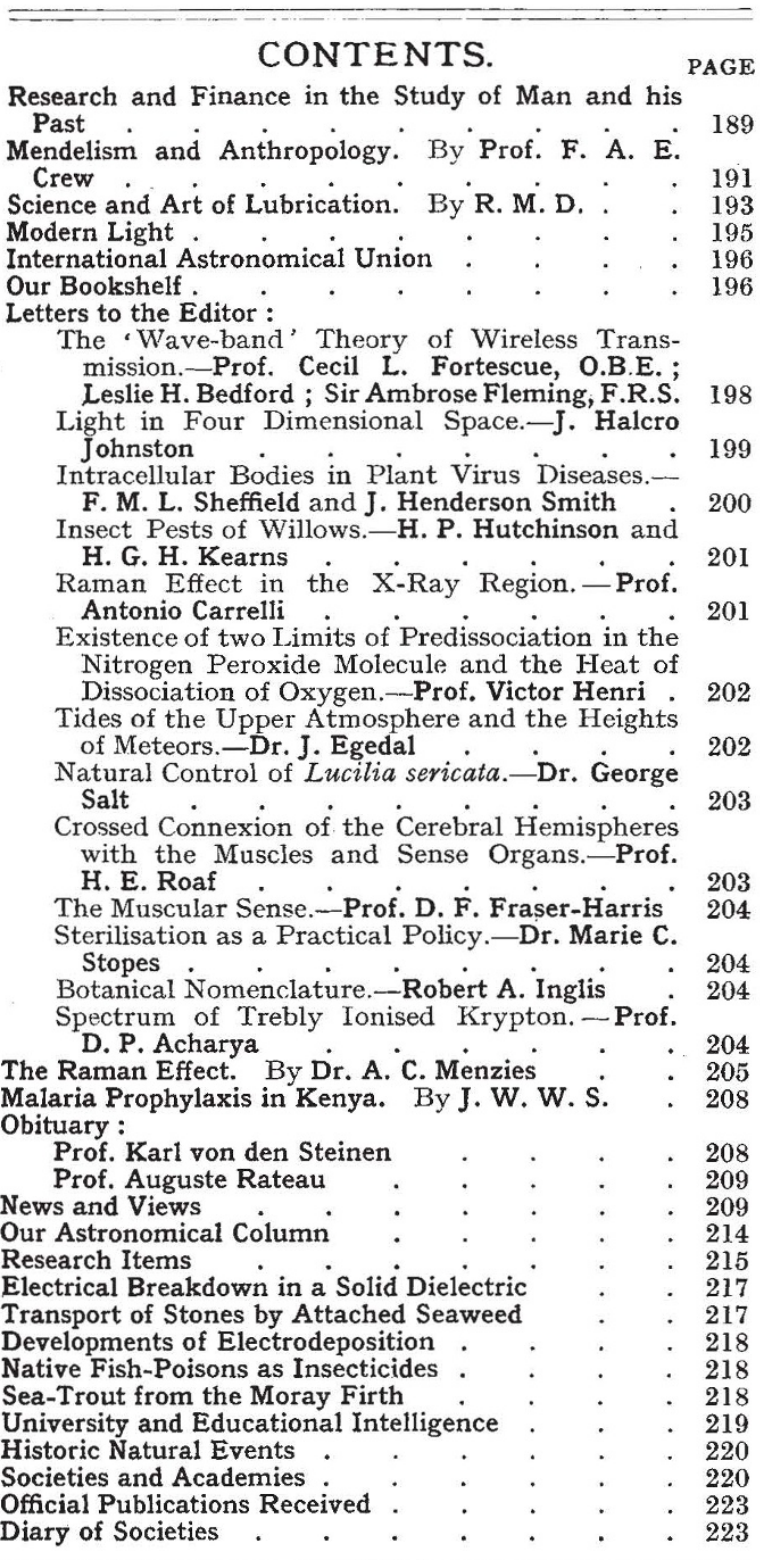

Editorial and Publishing Offices:

MACMILLAN \& CO., LTD.,

ST. MARTIN'S STREET, LONDON, W.C.2.

Telephone Number: GERRARD 8830.

Telegraphic Address: PHUSIS, WESTRAND, LONDON.

\section{Research and Finance in the Study of Man and his Past.}

$I^{\mathrm{s}}$ $\mathrm{N}$ a note which appeared in Nature of Feb. 1, p. 175, the announcement of the departure of the British Museum's expedition to British Honduras for the purpose of continuing the excavation of Mayan antiquities is coupled with a reference to an appeal by the Director of the Museum for funds to carry on the work and to ensure its continuation. It is held out as an inducement to subscribers, that the sites on which these investigations are being made are within imperial territory, and that this fact gives to British archæologists a security of tenure which they are unable to secure on any prehistoric site in the old world. That this is an element in archæological research of no little importance is indicated by the recent removal of the operations of the British School of Archæology in Egypt to Palestine, as well as by the experience of those who have continued to work in Egypt since changed conditions have prevailed. Even the intensely interesting archæological field which is opening up in India along the Indus Valley is not likely to offer rival attractions to Honduras in this respect, while at any rate investigation on important sites is primarily a function of the Archæological Survey. The Schools of Archæology in Iraq and Palestine operate in mandated territory, while those at Athens and Rome are naturally entirely subject to the regulations for the time being of their hosts. They may at any moment find their activities restricted, as happened in Greece a few years ago when the operations of foreign schools of archæology were limited to two sites in any one year. The expedition to British Honduras, therefore, it is justly claimed, enjoys a unique advantage in that it is working entirely within the boundaries of British territory.

We wish the Director's appeal every success; but while commending it strongly as in every way calling for the generous support of the public, it is in no spirit of criticism that we point out that it inevitably gives rise to a variety of reflections. It may be said without undue partiality that British field work in archæology has proved itself second to none in scientific methods of excavation and in the accurate and painstaking recording and preservation of results. Yet while our archæologists are to the fore in every field in the Old World, the New has been sadly neglected. Students in Britain of the archæology and cultures of America-North, Central, and South-are a small, if distinguished, body. If, however, there is one man who played the

No. 3145, VoL. 125] 
greatest part in establishing the modern study of Central American archæology, it is an Englishman, Dr. A. P. Maudslay, whose remarkable journeys of exploration brought back from the Central American forests, surmounting almost incredible difficulties, a wonderful series of plaster casts of Mayan antiquities which were afterwards presented to the nation.

The magnitude of this work has never been generally appreciated. The density of vegetation in the tropical forest made it a work of intense endurance even to reach the ruins and to clear them from the vegetation with which they were covered; but apart from that, every ounce of the plaster of Paris used in making these large casts was imported from England and carried by the expedition to the sites on which it was used. The total cost borne by Dr. Maudslay himself was at least $£ 10,000$, while the labour and time involved by his expeditions will be appreciated when it is remembered that Capt. Joyce's expedition to Pusilhá in 1929 with the aid of a motor tractor took eighteen days to cover a distance of 48 miles by land and river. For Honduras that was good progress. The whole way on land had to be cut through thick vegetation.

With a record of this character behind us in Americanist studies-without reference to the valuable contribution made by Capt. Joyce, both in his synthetic studies of American archæology and his original investigations-it seems incredible that the opportunity should be neglected. The attention of British archæologists should be attracted to a study of such interest and importance. A British school of American archæology should be built up to explore our own territory in Central America. The fields of the Old World offer an attraction which cannot be denied. They are beginning to link up the history of civilisation as a whole in time and space in a manner in which American archæology in its present isolation, apart from diffusionist views, cannot hope to do. The development of scientific method on Old World sites makes them admirable training grounds for the student; but American archæology presents its own problems in method, and it must be remembered that even here stratigraphical problems have to be solved even if the conditions differ, as can be seen in the work of American archæologists in the South-Western States, in Mexico Valley, and in some of the other recent investigations in Central and South America.

Further, in Central America it is difficult to forecast what the future may bring forth, for investiga- tion has still to demonstrate with certainty the beginnings of this culture. The opportunities for discovery seem to be practically unlimited. The short trial aeroplane flight made from Belize recently by Col. Lindbergh showed how many unknown ruins it was possible to sight in an area relatively restricted. When once the facts of the case are appreciated, they require no emphasis to press the need for the formation of such a school, perhaps on the lines of Sir Flinders Petrie's Egyptian school rather than of those at Athens and Rome. The British Museum's expedition, if placed on a permanent basis, might form its nucleus. It would be a graceful recognition of a great piece of work, which is a credit to British archæological studies, if it could in some way be linked with the name of Dr. Maudslay.

These matters, however, lie with the future. The British Museum's appeal is of the present. The British Museum appeals for funds for an expedition of exploration in a British Colony! In other words, a great national institution has to appeal to the generosity of the private individual to carry out work which its administration has decided is within its province and for which members of its own staff have been seconded. In this year's expedition the experienced and exceptionally qualified leader is unable to participate, owing, it is presumed, to his official duties as Deputy Keeper ; and part of the funds are derived from the generous gift of an American. For this gift we are grateful, but an expedition so essentially British should be able to rely if necessary upon British money.

The case of the Honduras Expedition is not singular. The excavations at Ur, which have produced results epoch-making in their revelation of the early history of civilisation, have also been carried out by an expedition of the British Museum ; but although the Museum authorities were well aware of the importance of the site, they did not feel justified in entering upon the financial responsibilities involved by its excavation until a joint expedition was proposed by the Museum of the University of Pennsylvania. Three seasons ago the excavation had to close down prematurely for lack of funds at a most important stage of its work, when the possibility of disturbance during the summer endangered the most momentous discoveries ever made on the site, as was shown immediately the work reopened in the following season.

It scarcely calls for argument that work which is considered sufficiently important to be carried on under the ægis of a national institution such as the

No. 3145 , VoL. 125] 
British Museum should not depend for its continuity upon the precarious generosity of the private individual. Such investigations are not undertaken with undue frequency, or without careful consideration of their intrinsic importance and their moment in the general advancement of knowledge. If they are undertaken, it is surely beneath our dignity that the Director should be in such a position that he must appeal to the individual citizen, or even to a foreign benefactor, to provide the funds to carry out what it has been decided after due consideration is a proper function of a national institution.

The Royal Commission on Museums and National Galleries has reported with admirable moderation and discretion; but it has shown that our national collections have been starved. The Report recognises the nation's indebtedness to the private benefactor in the past : it hopes that we may still rely upon the generosity of the individual in the future. Archæologieal exploration, however, is too often a matter of immediate opportunity, both in site and personnel, to depend upon fortuitous finance. It would be an excellent thing if a commission similar to that on the Museums were appointed to examine the question of State assistance to scientific research in general. Some provision is already made out of national funds for certain branches of research; but the benefits of this provision are practically confined to the physical sciences.

How much is done for the humanistic sciences? What funds are available for anthropology? A line has been drawn at physical anthropology, while the amounts available for archæology from the grants allocated by the Royal Society are, as a rule and relatively, almost negligible. It has been pointed out again and again that, through a lack of funds, enthnographic material within the Empire is being allowed to disappear rapidly as our primitive peoples come into contact with European culture. Archæological material is perhaps in better case; but if so, this is due to private benefaction and a greater interest taken in the subject by the public, who are sometimes prepared to give practical expression to that interest in the form of a subscription. Even so, financial resources are precarious and often inadequate.

The success of the appeal for a School of Archæology in Iraq was almost entirely a success of the personality of the late Miss Gertrude Bell. The appeal of the British School of Archæology in Palestine failed utterly, and that too at a time when the Government had withdrawn its temporary financial support. Here, however, if anywhere, might No. 3145 , VoL. 125] archæology have looked for sympathy and assistance from the public when it was engaged in investigating the early history of that country in which so many of our religious and intellectual antecedents are rooted. Palestine is the chief spiritual fount of the British peoples, but it is not the only one. We have British schools in other countries to which our civilisation is almost as deeply indebted. The schools at Athens and Rome have been generously supported by subscription and benefaction, but their means have been and continue to be inadequate to carry out fully the programme of instruction and research they have set themselves. Further, in each case they represent the British nation in almost an equal degree with the British Embassy. They provide an intellectual and academic, as well as a social, centre representative of the British nation, for visitors and residents alike. That their work should be endangered or restricted for lack of funds does us as a nation no credit.

The question of the subvention of research in humanistic studies from public funds opens up a wide field upon which it is not possible here to do more than touch. The archæology of Great Britain itself, for example, has its no less urgent needs. While claims on the public purse are many and the country is overburdened with taxation, a plea from any one department of knowledge may easily be set aside as inopportune on grounds of public policy. It is for this reason that for a reasoned verdict on the urgency of the plea we should look to a public inquiry into the present needs of research, especially in the humanistic sciences.

\section{Mendelism and Anthropology.}

Heredity in Man. By Prof. R. Ruggles Gates. Pp. xiii +385 . (London: Constable and Co., Ltd., 1929.) 24s. net.

A BOOK with a title "Heredity in Man" will A attract the attention of the many who are interested in human affairs, and who have been made aware of the proven usefulness of the contributions of the science of genetics to the practices of animal and plant breeding.

It will appeal strongly to such as hold the view that the further evolution of man, and therefore of society, will take the form of the conscious and deliberate manipulation by man of the attributes of his environment and of the mechanisms that are himself. These will agree with the statement in the preface that a knowledge of human heredity 